\title{
COMPUTER AIDED DESIGNING AND MODELLING OF SPUR GEAR PAIRS HAVING NORMAL AND MODIFIED STRAIGHT TEETH
}

\author{
SÁNDOR BODZÁS
}

Department of Mechanical Engineering, Faculty of Engineering, University of Debrecen, Ótemetö u. 2-4, H-4028 Debrecen, Hungary

E-mail: bodzassandor@eng.unideb.hu

The aim of this publication is to show the process of computer aided designing of the spur gear pairs having normal and modified straight teeth. For designing, the determination of the geometrical parameters is needed. Computer programs have been developed with which gear pairs having normal and modified teeth, with any arbitrary parameters can be analysed, designed and modelled. With these programs gear pairs having concrete geometry have been designed and CAD models have also been drawn to have further meshing, geometrical and TCA (Tooth Contact Analysis).

Keywords: spur gear having normal straight teeth, modified teeth, model, gear

\section{Introduction}

During machining of the tooth surfaces of the gear pair, tooth surfaces are cut by the tool base profile. The reference line of the tool can differ from the datum line, since the pitch circle of the gear can be rolled down not only on the datum line of the tool but any perpendicular pitch circles (Fig. 1) [5, 8].

If during cutting, the reference line of the tool does not overlap the datum line of the tool then we call it shifted cutter machining. The method can also be called 'addendum modification' where the datum line of the tool is shifted outward the pitch circle of the generated gear wheel. The value of the shift is given as a function of the module (xm), where $\mathrm{x}$ is the so called profile shift coefficient. This ( $\mathrm{x}$ ) is positive if the base profile is shifted outward from the shaft, it is negative when the base profile is shifted towards the shaft $[2$, $5,8]$. If the profile shift coefficient is zero, then the reference line of the tool is the same as the datum line of the tool which touches the pitch circle of the gear. This wheel is called a spur gear having standard teeth $[1,2,5,8,9]$.
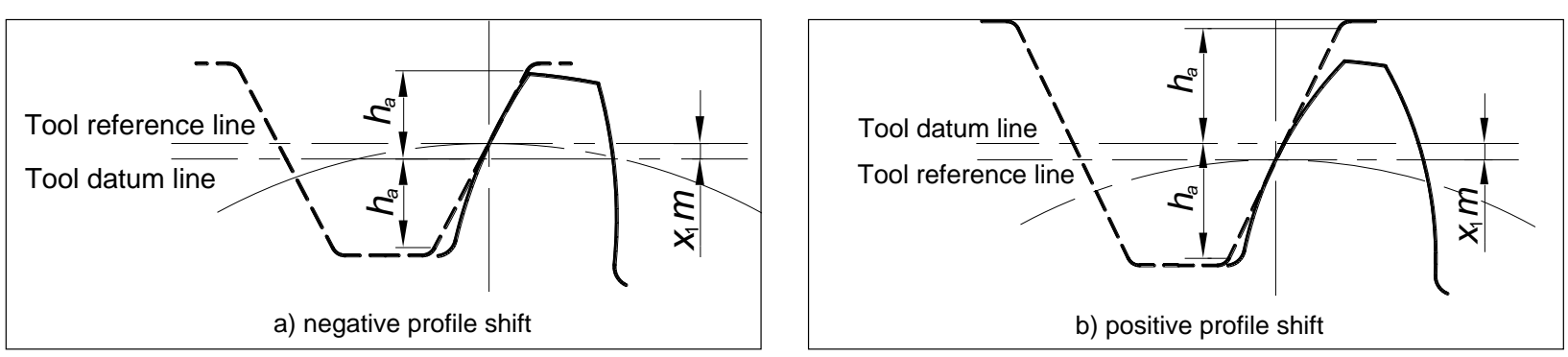

Fig. 1. Mating of the tool base profile with the tooth of the gear

Open Acces statement. This is an open-access article distributed under the terms of the Creative Commons Attribution 4.0 International License (https://creativecommons.org/licenses/by/4.0/), which permits unrestricted use, distribution, and reproduction in any medium, provided the original author and source are credited, a link to the CC License is provided, and changes - if any - are indicated. (SID_1) 


\section{Designing spur gear pair having normal straight teeth}

Profile shift is applied on the contact gears for designing the spur gear pair having normal straight tooth. In this case the meshing of the tooth of the mating gears is not along the pitch circle but along the working pitch circle (Fig. 2) [5,8].

The $m$ module is given, the $z_{1,} z_{2}$ number of teeth, $\alpha_{0}$ base profile angle and $\alpha_{g}$ angle of contact. Correlations used for designing the gear pair based in Fig. 2 are the following [8]:
1. Pitch circle diameters $\left(d_{1}, d_{2}\right)$ :

$$
d_{1,2}=z_{1,2} m
$$

2. Involute base circle diameters $\left(d_{b 1}, d_{b 2}\right)$ :

$$
d_{b 1,2}=d_{1,2} \cos \alpha_{0}
$$

3. Working pitch circle diameters $\left(d_{w 1}, d_{w 2}\right)$ :

$$
d_{w 1,2}=d_{b 1,2} / \cos \alpha_{g}
$$

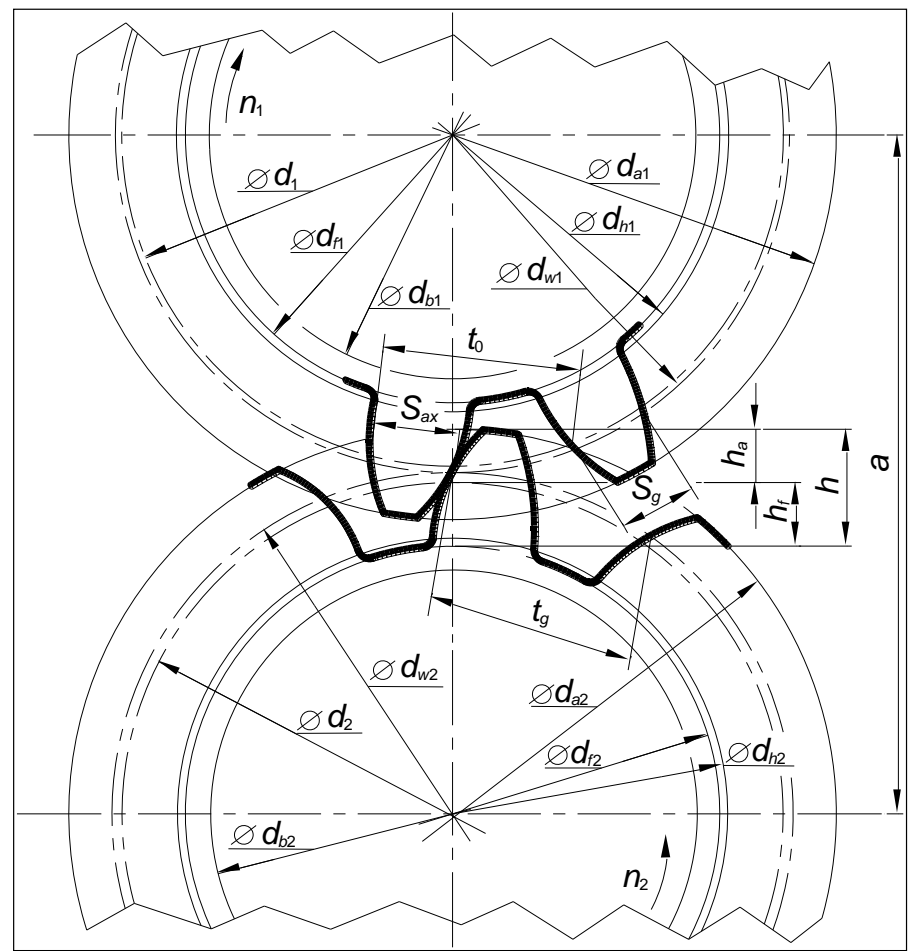

Fig. 2. The parameters of the spur gear pair having normal straight teeth

Table 1. Main parameters of the gear pair

\begin{tabular}{llll}
\hline Notation & Nomination & Notation & Nomination \\
\hline$d_{1}, d_{2}$ & Pitch circle diameter & $h_{f}$ & Dedendum \\
$d_{f 1}, d_{f 2}$ & Root circle diameter & $h_{a}$ & Addendum \\
$d_{a 1}, d_{a 2}$ & Tip circle diameter & $h$ & Whole depth \\
$d_{h 1}, d_{h 2}$ & Base circle diameter & $t_{g}$ & Circular pitch \\
$d_{w 1}, d_{w 2}$ & Working pitch circle diameter & $S_{a x}$ & Tooth thickness \\
$c$ & Bottom clearance & $m$ & Module \\
$h_{w}$ & Working depth & $z$ & Number of teeth \\
$a$ & Centre distance & $j_{s}$ & Backlash \\
$d_{b 1}, d_{b 2}$ & Involute base circle diameter & $\alpha_{0}$ & Base profile angle \\
$t_{g}$ & Circular pitch along working pitch circle & $S_{g}$ & Tooth thickness along working pitch circle \\
\hline
\end{tabular}


4. The sum of profile shift coefficients $(\Sigma x)$ :

$\Sigma x=x_{1}+x_{2}=\left[(1 / 2)\left(z_{1}+z_{2}\right)\right]\left[\left(\operatorname{inv} \alpha_{g}-\operatorname{inv} \alpha_{0}\right) / \operatorname{tg} \alpha_{0}\right](4)$

5. Centre distance $(a)$ :

$$
a=(1 / 2)\left(d_{g 1}+d_{g 2}\right)
$$

6. Standard centre distance $\left(a_{0}\right)$ :

$$
a_{0}=(1 / 2)\left(d_{1}+d_{2}\right)
$$

7. Centre distance larger than standard $(y)$ :

$$
y=(1 / m)\left(a-a_{0}\right)
$$

8. Mutual working depth $\left(h_{w}\right)$ :

$$
h_{w}=[2-(\Sigma x-y)]
$$

9. Addendum $\left(h_{a 1,2}\right)$ :

$$
h_{a 1,2}=(1 / 2) h_{k}
$$

10. Bottom clearance $(c)$ :

$$
c=c^{*} m,
$$

where $c^{*}=0.25$

11. Dedendum $\left(h_{f 1}, h_{f 2}\right)$ :

$$
h_{f 1,2}=h_{a 1,2}+c
$$

12. Whole depth $(h)$ :

$$
h_{1,2}=h_{a 1,2}+h_{f 1,2}
$$

13. Circular pitch $\left(t_{0}\right)$ :

$$
t_{0}=m \pi
$$

14. Circular pitch along working pitch circle $\left(t_{g}\right)$ :

$$
t_{g}=\left(\cos \alpha_{0} / \cos \alpha_{g}\right) t_{0}
$$

15. Tip circle diameter $\left(d_{a 1}, d_{a 2}\right)$ :

$$
d_{a 1,2}=d_{1,2}+2 h_{a 1,2}
$$

16. Root circle diameter $\left(d_{f 1}, d_{f 2}\right)$ :

$$
d_{f 1,2}=d_{1,2}-2 h_{f 1,2}
$$

17. Backlash $(j)$ :

$$
j=(1 / 20) p
$$

18. The $x_{1}$ profile shift coefficient:

$$
x_{1}=\left[\left(d_{g 1} / 2\right)-h_{f 1}\right] / \mathrm{m}-(1 / 2) z_{1}+h_{f 1} / \mathrm{m}+c^{*}
$$

19. The $x_{2}$ profile shift coefficient:

$$
x_{2}=\Sigma x-x_{1}
$$

20. Tooth thickness $\left(S_{a x 1}, S_{a x 2}\right)$ :

$$
S_{a x 1,2}=(1 / 2) t_{0}+2 x_{1,2} m \operatorname{tg} \alpha_{0}
$$

21. Tooth thickness along working pitch circle $\left(S_{g 1}\right.$, $\left.S_{g 2}\right)$ :

$$
S_{g 1,2}=d_{g 1, g 2}\left(\frac{S_{a x 1,2}}{d_{1,2}}+\operatorname{tg} \alpha_{0}-\widehat{\alpha}_{0}+\operatorname{tg} \alpha_{g}+\widehat{\alpha}_{g}\right)
$$

\section{Designing of spur gear pair having modified straight teeth}

The spur gear pairs having modified straight teeth are given as a borderline case when the spur gears mesh on the standard centre distance $\left(a_{0}\right)$ but the teeth of the gears are made by profile shift. Due to this fact the gear wheels contact along the pitch circle and the addition of the profile shift coefficient is $x_{1}+x_{2}=0$, that is $x_{1}=-x_{2}$. If we modify the tooth on one of the gear wheels then with the same value but with different indication you should correct the other gear wheel as well (Fig. 3) [5, 8]

Table 1 contains the applied signs. The $m$ module is given, $z_{1}, z_{2}$ number of teeth, $\alpha_{0}$ base profile angle, $f_{0}^{\prime}$ addendum coefficient, and $x_{1}$ profile shift coefficient. Correlations used for designing the gear pairs based on Fig. 3 are the following [8]:

1. Standard centre distance $\left(a_{0}\right)$ :

$$
a_{0}=(1 / 2)\left(z_{1}+z_{2}\right) m
$$

2. Addendum values of the gear wheels $\left(h_{a 1, a 2}\right)$ :

$$
\begin{aligned}
& h_{a 1}=f_{0}^{\prime} m+x_{1} m, \\
& h_{a 2}=f_{0}^{\prime} m-x_{1} m
\end{aligned}
$$

3. Bottom clearance $(c)$ :

$$
c=c^{*} m
$$

where $c^{*}=0.25$ 


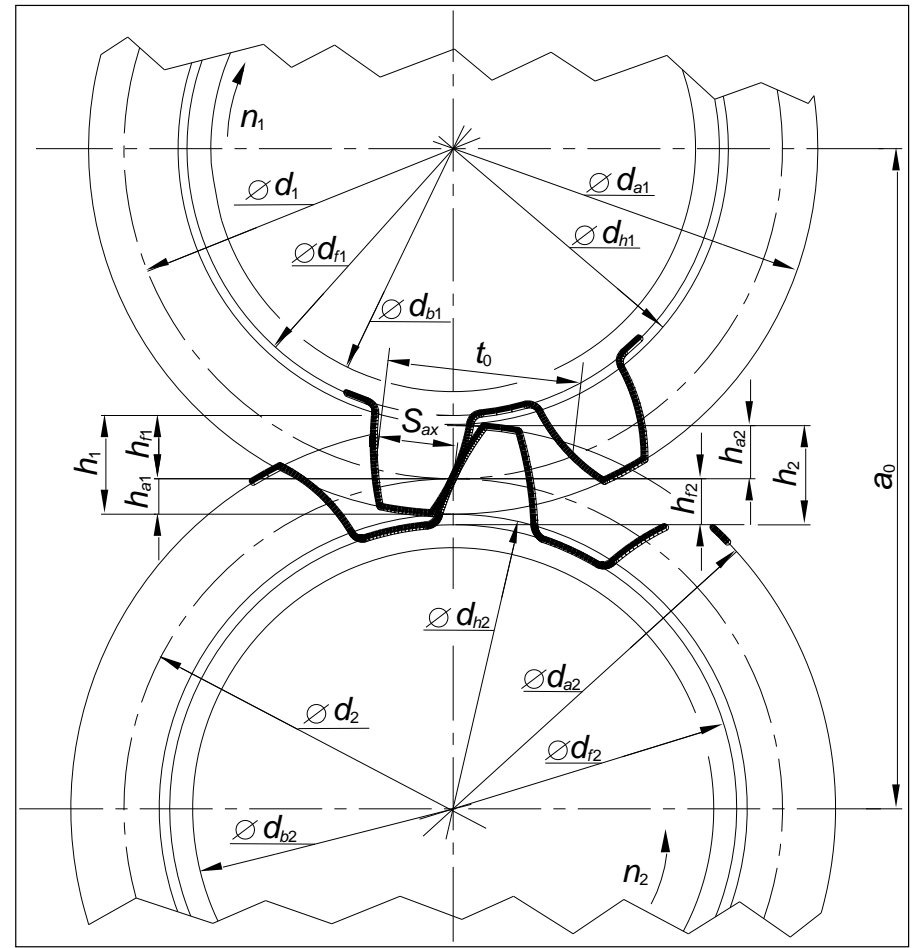

Fig. 3. Parameters of the spur gear pair having modified straight teeth

4. Dedendum $\left(h_{f 1}, h_{f 2}\right)$ :

$$
h_{f 1,2}=h_{a 1,2}+c
$$

5. Whole depth $\left(h_{1,2}\right)$ :

$$
h_{1,2}=2 f_{0}^{\prime} m+c
$$

6. Circular pitch $\left(t_{0}\right)$ :

$$
t_{0}=m \pi
$$

7. $\operatorname{Backlash}(j)$ :

$$
j=(1 / 20) p
$$

8. Working depth $\left(h_{w}\right)$ :

$$
h_{\mathrm{w}}=2 f_{0}^{\prime} m
$$

9. Tooth thickness $\left(S_{a x}\right)$ :

$$
S_{a x}=(1 / 2) t_{0}-(1 / 2) j_{s}
$$

10. Pitch circle diameters $\left(d_{1}, d_{2}\right)$ :

$$
d_{1,2}=z_{1,2} m
$$

11. Tip circle diameters $\left(d_{a 1}, d_{a 2}\right)$ :

$$
d_{a 1,2}=d_{1,2}+2 h_{a 1,2}
$$

12. Root circle diameters $\left(d_{f 1}, d_{f 2}\right)$ :

$$
d_{f 1,2}=d_{1,2}-2 h_{f 1,2}
$$

13. Involute base circle diameter $\left(d_{b 1}, d_{b 2}\right)$ :

$$
d_{b 1,2}=d_{1,2} \cos \alpha_{0}
$$

\section{Mathematical modelling}

For the modelling and contact analysis of the drive pair we draw the necessary coordinate system layout (Fig. 4) [1, 3, 4, 7].

The profile of the gear pair, i.e. the equation of the involute of a circle, in $K_{1 R}\left(x_{1 R}, y_{1 R}\right)$ coordinate system (Fig. 4):

$$
\left.\begin{array}{l}
x_{1 R}=\frac{d_{a k 1}}{2} \cdot(\cos \beta+\beta \sin \beta) \\
y_{1 R}=\frac{d_{a k 1}}{2} \cdot(\sin \beta-\beta \cos \beta)
\end{array}\right\} .
$$

We are looking for the tooth curve connected to $K_{2 R}$ that mates with $\vec{r}_{1 R}=\vec{r}_{1 R}(\beta)$ tooth curve. We use the fact that the 2 teeth surfaces during moving are 


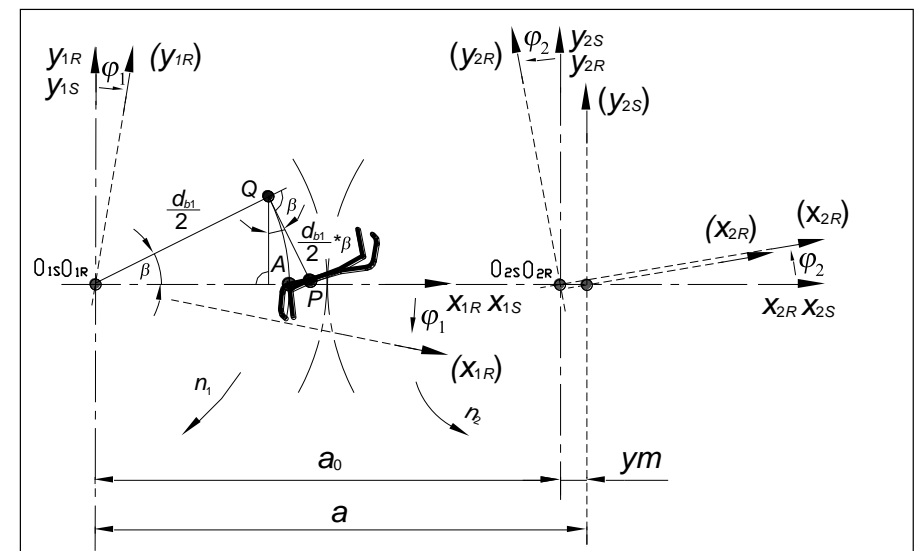

Fig. 4. The coordinate system used for modelling the contact analysis of the gear pair

overlapping each other and if we take into consideration the following correlation:

$$
\varphi_{2}=i_{21} \varphi_{1}
$$

then we can state that the overlapping movement can be described with a movement parameter $\left(\varphi_{1}\right)[3,4,7]$. The transformation matrix between $K_{1 R}$ and $K_{2 R}$ rotating coordinate systems is the following:

$$
M_{2 R, 1 R}=\left[\begin{array}{ccc}
\cos \varphi_{2} \cos \varphi_{1} & \cos \varphi_{2} \sin \varphi_{1} & -a(-y m) \cos \varphi_{2} \\
-\sin \varphi_{2} \sin \varphi_{1} & +\sin \varphi_{2} \cos \varphi_{1} & \\
\sin \varphi_{2} \cos \varphi_{1} & -\sin \varphi_{2} \sin \varphi_{1} & a(-y m) \sin \varphi_{2} \\
+\sin \varphi_{1} \cos \varphi_{2} & +\cos \varphi_{2} \cos \varphi_{1} & \\
0 & 0 & 1
\end{array}\right] .
$$

On the tooth surfaces of the contact members, as a contact line on overlapping surfaces, it can be described by solving both the contact equation - which expresses the I. Law of Contact

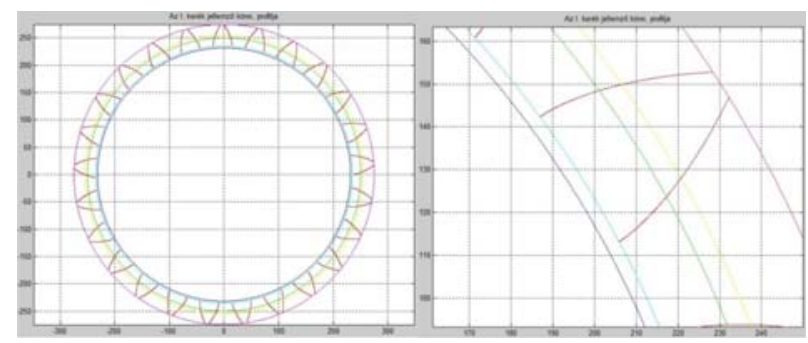

a) creating the driving gear wheel

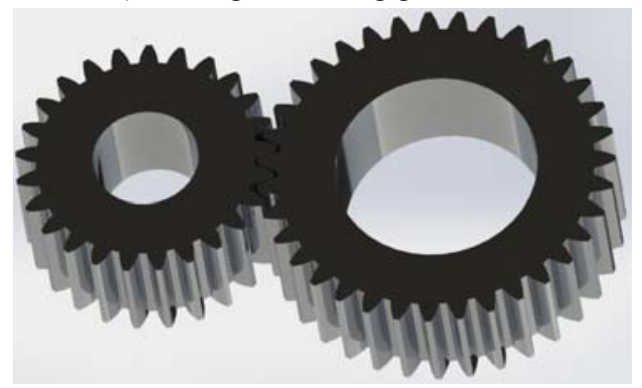

c) creating the $\mathrm{CAD}$ model

$$
\vec{n}_{1 R} \vec{v}_{1 R}^{(12)}=\vec{n}_{2 R} \vec{v}_{2 R}^{(12)}=\vec{n} \vec{v}^{(12)}=0
$$

and the vector-scalar function which expresses the tooth surface (Fig. 4) [3, 4, 7].

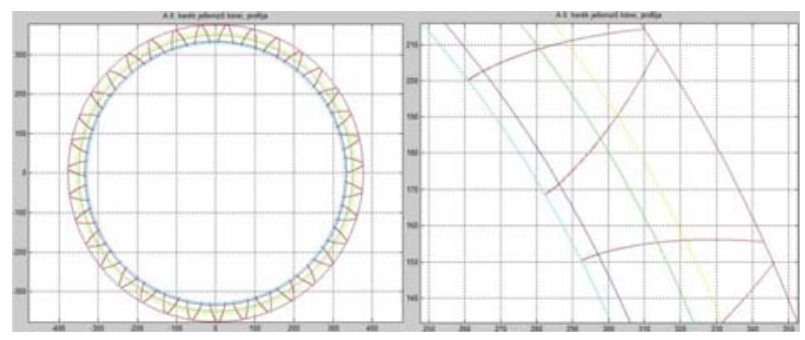

b) creating the driven gear wheel
Fig. 5. Modelling of spur gear pair having normal, straight teeth $\left(m=10, z_{1}=25, z_{2}=35, \alpha_{0}=20^{\circ}, \alpha_{g}=23^{\circ}\right)$ 


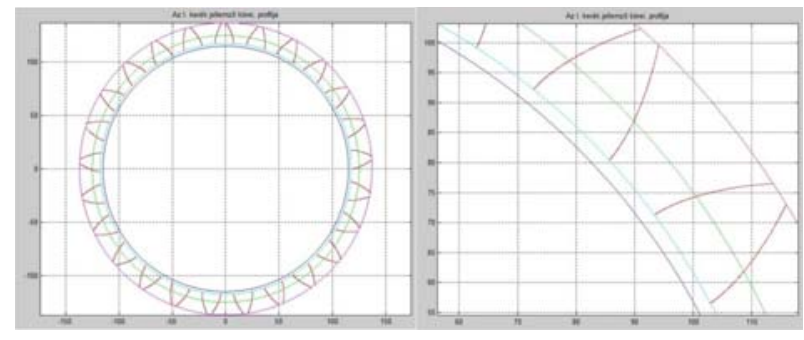

a) creating the driving gear wheel

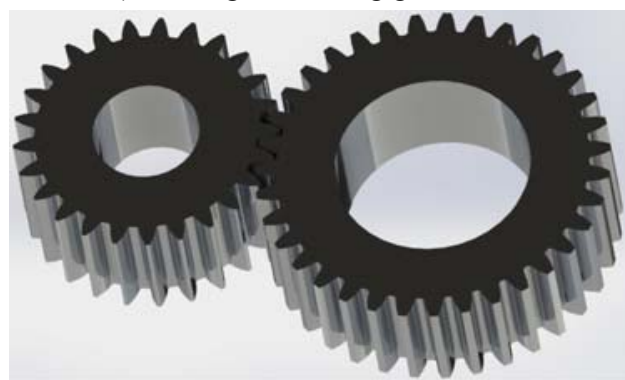

c) creating the $\mathrm{CAD}$ model

The equations of the tooth surfaces of the second member, created as the overlapping surface of the contact line group in $\mathrm{K}_{2 \mathrm{R}}$ coordinate system are the following $[3,4,7]$ :

$$
\left.\begin{array}{l}
\vec{n}_{1 R} \vec{v}_{1 R}^{(12)}=0, \\
\vec{r}_{1 R}=\vec{r}_{1 R}(\beta), \\
\vec{r}_{2 R}=M_{2 R, 1 R} \vec{r}_{1 R},
\end{array}\right\}
$$

where the equation of the normal vector is:

$$
\left.\begin{array}{l}
n_{1 R}=\frac{d_{a k 1}}{2} \beta \cos \beta \\
n_{1 R}=\frac{d_{a k 1}}{2} \beta \sin \beta
\end{array}\right\}
$$

\section{Modelling by computer}

With the help of the mathematical correlations mentioned above, computer programs were developed for designing the spur gear pairs having normal and modified teeth. The program calculates the significant parameters of the drive pair (centre distance, typical circles etc.) and it draws the gear wheels. The profile points of the wheel can be saved in txt file format and can be imported into 3D engineering design software (Figs 5 and 6).

The interpolating, B spline surface is matched to the given profile points [6]. From the involute tooth we made body elements by extruding, which is modelled along a circumference of a given wheel appropriate for the number of teeth (Fig. 5c and 6c).

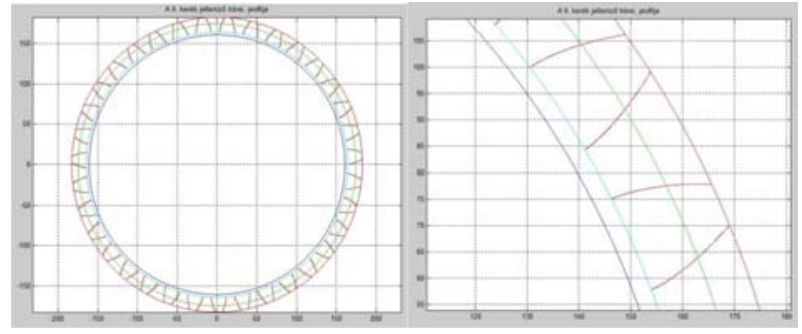

b) creating the driven gear wheel

Fig. 6. Modelling of the spur gear pair having modified straight teeth $\left(m=10, z_{1}=25, z_{2}=35, \alpha_{0}=20^{\circ}, f_{0}^{\prime}=1, x_{1}=0.2\right)$

\section{Summary}

Geometrical correlations have been shown for designing the spur gear pairs having normal and modified straight teeth. The tooth surface of the driven gear wheel mating the driver gear has been determined by direct kinematic method.

For designing and modelling of the gear pairs computer programs have been created. The softwares calculate the dimensions of the gear pairs from the input data and they draw the model of the gear pairs.

By importing the involute profile curve points into $3 \mathrm{D}$ designing program and match the points with the interpolating, B spline surface, the CAD model of the drive pair has been created. This process has been applied for modelling drive pairs having concrete geometry.

With the help of our gear designing softwares by changing the input data - any kind of geometrical spur gear pairs having standard, normal and modified straight teeth can be designed then modelled. With the use of the CAD models further contact-, geometricaland TCA analyses can be made.

\section{Acknowledgements}

This research was supported by the János Bolyai Research Scholarship of the Hungarian Academy of Sciences.

\section{References}

[1] Bodzás S. (2017), Computer aided designing and modelling of x-zero gear drive. International Review of Ap- 
plied Sciences and Engineering, 8(1), 93-97. DOI: 10.1556/1848.2017.8.1.13

[2] Dudás I. (2011), Gépgyártástechnológia III., A. Megmunkáló eljárások és szerszámaik, B. Fogazott alkatrészek gyártása és szerszámaik. Műszaki Kiadó, Budapest.

[3] Dudás I. (2016), The extension of the general mathematical model developed for helicoical surfaces to the whole system of manufacturing technology and production geometry (ProMAT). International Journal of Advanced Manufacturing Technology, 86(5-8), 1557-1572. DOI: 10.1007/s00170-015-8233-5

[4] Dudás L. (1991), Kapcsolódó felületpárok gyártásgeometriai feladatainak megoldása az elérés modell alapján. Kandidátusi értekezés, Budapest, p. 144.
[5] Erney Gy. (1983), Fogaskerekek. Müszaki Könyvkiadó, Budapest, p. 460.

[6] Juhász I. (1993, 1995), Számítógépi Geometria és Grafika. Miskolci Egyetemi Kiadó, Miskolc, p. 220

[7] Litvin F. L., Fuentes A. (2004), Gear Geometry and Applied Theory, Cambridge University Press, ISBN 9780 521815178

[8] Terplán Z. (1975), Gépelemek IV. Kézirat, Tankönyvkiadó, Budapest, p. 220.

[9] Gołębski R. Željko I. (2017), Analysis of modification of spur gear profile. Technical Gazette, 25(2), 643-648. 